\title{
DIFFERENCES IN EATING PATTERNS OF MIDDLE SCHOOL STUDENTS LIVING IN URBAN AND RURAL AREAS LOCATED IN THE MASOVIAN VOIVODESHIP
}

\author{
Marzena Malara ${ }^{1}$, Natalia Zaleskal, Grażyna Lutosławska ${ }^{l}$ \\ ${ }^{1}$ Józef Piłsudski University of Physical Education in Warsaw, Depatment of Biochemistry and Biology, \\ 34 Marymoncka Str, 00-968 Warsaw, Poland
}

\begin{abstract}
Background. Proper eating behaviours among youth condition their bodies' optimal growth and development and impact future diet choices, which affects maintenance of health in later years. Studies concerning assessment of the way of eating among adolescents in Poland over the past years indicate a number of errors.

Objective. The aim of these studies was to asses diet diversity of middle school students, living in urban and rural areas located in the Masovian Voivodeship.

Material and methods. 180 people participated in this study, 90 girls and 90 boys in age between 13 and 15 years. They were middle school students, living in urban and rural areas of Mazowieckie Voivodeship. Assessment of the variety of eating pattern amongst participants were conducted using the Food Intake Diversification Questionnaire (FIVeQ).

Results. It was found that $3.3 \%$ of respondents from rural areas and $10 \%$ of respondents from urban areas were characterized by inappropriate variation of food intake. Sufficient variation of food consumption was found among $35.5 \%$ respondents from rural areas and $36.6 \%$ from urban areas. Good variation of food consumption was demonstrated in $54.4 \%$ of subjects from rural areas and in $42.2 \%$ from urban areas. Very good variation of food consumption was found in $6,6 \%$ of subjects from rural areas and $11.1 \%$ from urban areas. It is worth noticing differences in diet variations observed in these studies. It was shown that diet variety at inadequate, good and very good level was significantly different between groups, which may be puzzling considering the fact that all subjects were living in the same Voivodeship.

Conclusion. For reason being, results obtained in these studies indicate the need for education of young people on principles of balanced way of eating.
\end{abstract}

Key words: eating behaviours, middle school students, variety of eating pattern

\section{STRESZCZENIE}

Wprowadzenie. Prawidłowe zachowania żywieniowe młodzieży warunkują optymalny wzrost i rozwój organizmu, a także mają istotny wpływ na wybory dietetyczne dokonywane w przyszłości, które rzutują na utrzymanie zdrowia w późniejszych latach. Wyniki badań dotyczących oceny sposobu żywienia młodzieży w Polsce na przestrzeni minionych lat wykazały liczne błędy.

Cel badań. Celem niniejszych badań była ocena urozmaicenia sposobu żywienia młodzieży gimnazjalnej zamieszkującej tereny miejskie oraz wiejskie zlokalizowane na obszarze województwa mazowieckiego.

Materiał i metody. W badaniu wzięło udział łącznie 180 osób, w tym 90 dziewcząt oraz 90 chłopców w wieku od 13 do 15 lat, uczniów z gimnazjów położonych na terenach miejskich i wiejskich, zlokalizowanych w województwie mazowieckim. Ocenę urozmaicenia sposobu żywienia wśród uczestników badań, przeprowadzono z wykorzystaniem kwestionariusza urozmaicenia spożycia żywności FIVeQ.

Wyniki. Stwierdzono, że nieodpowiednim urozmaiceniem spożycia żywności charakteryzowało się 3,3\% badanych $\mathrm{z}$ terenów wiejskich oraz $10 \%$ badanych z terenów miejskich. Wystarczającym urozmaiceniem spożycia żywności charakteryzowało się $35,5 \%$ badanych z terenów wiejskich oraz 36,6\% zamieszkujących tereny miejskie. Jednocześnie dobre urozmaicenie spożycia żywności wykazano u 54,4\% mieszkańców wsi, a także 42,2\% mieszkańców terenów miejskich. Natomiast bardzo dobrym urozmaiceniem spożycia żywności charakteryzowało się 6,6\% mieszkańców obszarów wiejskich oraz 11,1\% obszarów miejskich. Warto przy tym zwrócić uwagę na różnice w sposobie urozmaicenia diety zaobserwowane w niniejszych badaniach. Wykazano bowiem, że urozmaicenie diety na poziomie niewystarczającym,

Corresponding author: Marzena Malara, Zakład Biochemii i Biologii, Katedra Nauk Biomedycznych, Akademia Wychowania Fizycznego Józefa Piłsudskiego, ul. Marymoncka 34, 00-968 Warszawa, Polska e-mail: marzena.malara@awf.edu.pl

(C) Copyright by the National Institute of Public Health - National Institute of Hygiene 
dobrym i bardzo dobrym różniło się istotnie między grupami, co może być zastanawiające z uwagi na fakt, że wszyscy ankietowani zamieszkiwali to samo województwo.

Wnioski. Wyniki uzyskane w niniejszych badaniach wskazują, na potrzebę edukowania młodzieży w kwestii zasad racjonalnego sposobu żywienia.

Słowa kluczowe: zwyczaje żywieniowe, gimnazjaliści, urozmaicenie diety

\section{INTRODUCTION}

Proper eating behaviours among youth condition their bodies' optimal growth and development and impact future diet choices, which affects maintenance of health in later years [11]. Both deficit and excess of nutrients have negative impact on health. Deficiencies of nutrients in adolescents diet may result in: malfunction of immune system, disordered bone tissue development, decrease in concentration, irritability or worse outcomes in education. On the other hand excess energy intake from diet contributes to development of overweight and obesity, with all their consequences in form of diet related diseases, otherwise called chronic non-infectious diseases [3]. It is worth noticing the fact that young people's eating patterns are usually a reflection of their parents lifestyle or other close people in their environment [7].

Studies concerning assessment of the way of eating among adolescents in Poland over the past years indicate a number of errors. The most common ones include excessive consumption of simple sugars, animal fats, table salt, as well as low consumption of fish, milk and dairy, vegetables and fruits $[8,20]$. At the same time their diet may be characterised by: irregularity in eating main meals, frequent skipping them or eating in between. It is worth mentioning that youth's diet rarely varies in food options, and rising popularity of weight-loss diets, especially amongst girls living in bigger cities, leads to deficiencies in micro- and macronutrients [26]. On the contrary greater variety of food often increases food intake and in a short time may affect body's energy balance [21].

Taking into consideration that puberty favors shaping and consolidating eating behaviours and the fact that there exist clear differences between eating patterns of adolescents conditioned by the place of residence, the aim of these studies was to asses diet diversity of middle school students, living in urban and rural areas located in the Masovian Voivodeship.

\section{MATERIAL AND METHODS}

\section{Study participants}

180 people (90 girls and 90 boys in age 13-15 years) participated in this study. They were middle school students, living in urban and rural areas of Mazowieckie Voivodeship. Studies were conducted after obtaining permission from school principal, class teachers, parents and local ethics committee. All participants were weighed and measured, which allowed to calculate BMI and its interpretation on centile grids developed by the Mother and Child Institute [16].

\section{Assessment of the variety of consumption}

Assessment of the variety of eating pattern amongst participants were conducted using the FIVeQ food intake diversification questionnaire [15]. It provides information about consumption of 63 product groups, which represent 8 main food groups: drinks, fruit, meat products, fish, eggs, dairy products, cereals and potatoes, sweets and snacks, fats and vegetables. The number of products eaten during one week (without alcoholic beverages) was considered a measure of the variety of food consumption. Questionnaire consists of 78 questions. Each one was answered by the students by choosing YES or NO. Only YES answer was scored 1 point. After calculating answers, the result of the variety of food intake of the study participants was obtained. The maximum score that could be obtained in the above-mentioned questionnaire was 60 points. According to interpretation of the questionnaire subjects who scored less than 20 points are characterized by inadequate variety, 20-29 points adequate variety, 30-39 points good variety, 40 and more very good variety.

\section{Statistical analysis}

All analyses were performed with the use of Statistica v.12 (StatSoft, USA). Results were expressed as mean values $\pm \mathrm{SD}$. Normality of distributions was analyzed using the Shapiro-Wilk test. Significance of differences between individual pairs of averages was evaluated using a two-factor ANOVA analysis. Differences in the diet of the study's participants, analyzing the variation of the diet, were evaluated using the Fisher's exact Chi-square test. The differences were taken as significant at $\mathrm{p}<0.05$.

\section{RESULTS}

The general characteristics of studied groups are presents in Table 1. Both groups of research subjects were in similar age. No statistically significant differences in terms of height and weight were noticed. All participants had BMI index value in the normal range. However it was shown, that the group 
of participants living in rural areas was characterized by a significantly lower BMI index in comparison with the group of participants living in urban areas.

Table 1. Subjects characterization (mean \pm SD)

\begin{tabular}{|l|c|c|}
\hline \multirow{2}{*}{} & \multicolumn{2}{|c|}{ Subject groups } \\
\cline { 2 - 3 } & $\begin{array}{c}\text { Rural areas } \\
(\mathrm{n}=90)\end{array}$ & $\begin{array}{c}\text { Urban areas } \\
(\mathrm{n}=90)\end{array}$ \\
\hline Age (years) & 14 & 15 \\
\hline Hight $(\mathrm{cm})$ & $160 \pm 0.05$ & $159 \pm 0.05$ \\
\hline Body weight $(\mathrm{kg})$ & $55.45 \pm 5.56$ & $56.91 \pm 5.40$ \\
\hline BMI & $21.61 \pm 1.35^{\mathrm{A}}$ & $22.25 \pm 1.81$ \\
\hline
\end{tabular}

A - statistically significantly lower compared to the group from the urban area $(\mathrm{p}<0.008)$

Analysis of variety of food consumption amongst study participants is shown in (Table 2). It was found that $3.3 \%$ of respondents from rural areas and $10 \%$ of respondents from urban areas were characterized by inappropriate variation of food intake. Sufficient variation of food consumption was found among $35.5 \%$ respondents from rural areas and $36.6 \%$ from urban areas. Good variation of food consumption was demonstrated in $54.4 \%$ of subjects from rural areas and in $42.2 \%$ from urban areas. Very good variation of food consumption was found in $6.6 \%$ of subjects from rural areas and $11.1 \%$ from urban areas. It was also shown that the incidence of inadequate variety of food intake was significantly lower in the group of residents of rural areas comparing to residents of urban areas. Analyses shown that there were no significant differences in the prevalence of varying food intake at a sufficient level between groups. The prevalence of a good variety of food intake in the group of rural residents was significantly higher, whereas very good was significantly lower comparing to the urban residents.

Table 2. Food consumption variety analysis among subjects evaluated based on FIVeQ questionnaire

\begin{tabular}{|c|c|c|}
\hline \multirow{2}{*}{$\begin{array}{c}\text { Variety of } \\
\text { consumption }\end{array}$} & \multicolumn{2}{|c|}{ Subject groups } \\
\cline { 2 - 3 } & $\begin{array}{c}\text { Rural areas } \\
(\mathrm{n}=90)\end{array}$ & $\begin{array}{c}\text { Urban areas } \\
(\mathrm{n}=90)\end{array}$ \\
\hline$<20$ & $3.3^{\mathrm{a}}(3)^{\mathrm{bA}}$ & $10(9)$ \\
\hline $20-29$ & $35.5(32)$ & $36.6(33)$ \\
\hline $30-39$ & $54.4(49)^{\mathrm{B}}$ & $42.2(38)$ \\
\hline$\geq 40$ & $6.6(6)^{\mathrm{A}}$ & $11.1(10)$ \\
\hline
\end{tabular}

${ }^{a}$ the percentage of the group; ${ }^{b}$ number of people

A - statistically significantly lower compared to the group of participants from the urban area $(\mathrm{p}<0.05)$

B - statistically significantly higher compared to the group of participants from the urban area $(\mathrm{p}<0.05)$

\section{DISCISSION}

In this research way of variation of food consumption amongst students attending middle schools in urban and rural areas localised in Masovian
Voivodeship was analysed. It should be noticed that a lot of studies evaluating adolescents' eating habits are focused mainly on group of participants from one place of residence. Whereas in presented studies subjects were recruited from six different schools from area of Masovian Voivodeship. Also validated way of evaluating variety of consumption - Food Frequency Questionnaire was used in these studies. Recurrence of the research results with use of this questionnaire, lets us to consider it as useful measurement tool, which is reliable source of information about frequency and quantity of food customarily consumed [24]. That's why in foreign literature similar questionnaires constitute commonly used research tool [1, 5, 14, 25].

Presented studies demonstrated that middle school students from rural areas were characterised by more inadequate variety of consumption in comparison with students from urban areas. Studies done by other authors confirm that adolescents diet is not varied enough and mainly consists of sandwiches [2, 11, 22]. Studies done by Chęcińska et al. [4] showed that adolescents from rural areas makes more nutritional errors compared with kids from urban areas. At the same time the other authors showed that place of habitat does not have significant impact on level of diet variety $[19,23]$

In these studies $50 \%$ of teens living on urban areas and more than $40 \%$ of teens from rural areas were characterised by good diet variety. However in research done by Marcysiak et al. [12] it was shown that more beneficial eating behaviours were presented by students from urban areas, while satisfying eating behaviours were presented by $10 \%$ of subjects. High level of diet variety was shown only in $1 \%$ of respondents.

Results obtained in mentioned research prove that very good diet variety was presented in very little number of subjects. Bigger assortment of consumed products was found amongst urban residents. Similar correlations were found in research done by MichotaKatulska et al. [13]. Author noticed that middle school adolescents living in urban areas consumed more vegetables, fruits, grain products, milk and meat compared to students from rural areas. Such correlations are also shown by other authors [9, 17]. At the same time results from Pieszko-Klejnowska et al. [18] and Flight et al. [6] research show that students from urban areas have more varied diet comparing to students from rural areas.

Our own research confirms other authors observation about middle school students consuming too much simple sugars, animal fats and to little of fish, milk and dairy, fruits and vegetables. It is worth noticing differences in diet variations observed in these studies. It was shown that diet variety at inadequate, good and very good level was significantly different between groups, which may be puzzling considering the fact that all subjects were living in the same Voivodeship. 
It cannot be ruled out that in this situation it was not place of residence being the main factor impacting observed differences. Based on the results obtained from the questionnaire only $3.3 \%$ of middle school students from rural areas and $10 \%$ form urban areas were characterized by inadequate diet variety. It also cannot be ruled out that in this group of respondents little diet variety will favour occurrence of nutrient deficiencies. However, on the other hand, among the rest of the study participants, the larger range of products consumed, including products with low nutritional value and high calorie, not only does not guarantee coverage of nutrient needs, but may contribute to the development of overweight or obesity.

\section{CONCLUSION}

The results of these studies indicate the need to educate young people on the principles of balanced way of eating.

\section{Conflict of interest}

The authors declare no conflict of interest.

\section{REFERENCES}

1. Assaad S., Chaaban R., Tannous F., Costanian C.: Dietary habits and Helicobacter pylori infection: a cross sectional study at a Lebanese hospital. BMC Gastroenterol 2018,doi: 10.1186/s12876-018-0775-1.

2. Bartkowska O., Bartkowski M.: Świadomość żywieniowa młodzieży gimnazjalnej w Komorowie. [Dietary consciousness of youths aged 13 - 15 years from Komorów]. Zeszyty Naukowe WSKFiT 2016;11:69-74 (in Polish).

3. Chabros E., Charzewska J., Chojnowska Z., Jarosz M., Mojska H., Ottarzewski M., Rogalska-Niedźwiedź M., Rychlik E., Szponar L., Traczyk I., Wajszczyk B., Walkiewicz A., Wierzejska R., Wolnicka K.: Zasady prawidłowego żywienia dzieci i młodzieży oraz wskazówki dotyczące zdrowego stylu życia. [The rules of proper nutrition for children and adolescents and tips for a healthy lifestyle]. Instytut Żywności i Żywienia, Warsaw, 2008 (in Polish).

4. Chęcińska Z., Krauss H., Hajduk M., BiałeckaGrabarz K.: Ocena sposobu żywienia młodzieży wielkomiejskiej i obszarów wiejskich. [Assessment of eating habits in urban and rural youth]. Probl Hig Epidemiol 2013;94(4):780-785 (in Polish).

5. Farhangi M., Jahangiry L.: Dietary diversity score is associated with cardiovascular risk factors and serum adiponectin concentrations in patients with metabolic syndrome. BMC Cardiovasc Disord 2018,doi: 10.1186/ s12872-018-0807-3.

6. Flight I., Leppard P., Cox D.: Food neophobia and associations with cultural diversity and socio-economic status amongst rural and urban Australian adolescents. Appetite 2003;41(1):51-9.
7. Jeżewska-Zychowicz M.: Zachowania żywieniowe młodzieży warszawskiej a środowisko społeczne. [Nutritional behaviors of Warsaw youth and social environment]. SGGW, Warsaw, 2005 (in Polish).

8. Klebaniuk R., Grela E.: Ocena żywienia wybranej grupy młodzieży szkolnej Lubelszczyzny. [Assessment of nutrition of a selected group of schoolchildren in the Lublin region]. Polish Journal of Human Nutrition 2009;36(1):193-200 (in Polish).

9. Komosińska K., Woynarowska B., Mazur J.: Zachowania zdrowotne związane z żywieniem u młodzieży szkolnej w Polsce w latach 1990-1998. [Health behaviors related to nutrition in school youth in Poland in the years 1990-1998]. Żywienie Człowieka i Metabolizm 2001;28(1):17-29 (in Polish).

10. Kowalcze K.: Wybrane zachowania żywieniowe i sposób żywienia gimnazjalistów warszawskiego Ursynowa. [Selected nutritional behaviors and feeding habits of junior high school students from Ursynów in Warsaw]. The importance of rational nutrition in health education. A. Wolska-Adamczyk, WSIiZ, Warsaw, 2015 (in Polish).

11. Maksymowicz-Jaroszuk J., Karczewski J.: Ocena zachowań i zwyczajów żywieniowych gimnazjalistów $\mathrm{z}$ terenu Białegostoku. [Assessment of nutritional behaviors and habits of junior high school students from the Bialystok area]. Hygeia Public Health 2010;45(2):167-172 (in Polish).

12. Marcysiak M., Zagroba M., Ostrowska B., Wiśniewska E., Marcysiak M., Skotnicka-Klonowicz G.: Aktywność fizyczna a zachowania żywieniowe dzieci i młodzieży powiatu ciechanowskiego. [Physical activity versus nutritional habits of children and teenagers in Ciechanów district]. Nursing Topics 2010;18(2):176183 (in Polish).

13. Michota-Katulska E., Zegan M., Zyznowska W., Siń B., Kucharska A.: Wybrane elementy stylu życia młodzieży gimnazjalnej. [Selected lifestyle elements of secondary school students]. Pielęgniarstwo Polskie 2015;56(2):121-125 (in Polish).

14. Morel S., Portolese O., Chertouk Y., Leahy J., Bertout L., Laverdière C., Krajinovic M., Sinnett D., Levy E., Marcil $V$ : : Development and relative validation of a food frequency questionnaire for French-Canadian adolescent and young adult survivors of acute lymphoblastic leukemia. Nutr J 2018,doi:10.1186/ s12937-018-0355-9.

15. Niedźwiedzka E., Wądołowska L.: Accuracy analysis of the Food Intake Variety Questionnaire (FIVeQ). Reproducibility assessment among older people. Pakistan J Nutr 2008;7(3):426-435.

16. Palczewska I., Niedzwiedzka Z.: Somatic development indices in children and youth of Warsaw. Med Wieku Rozwoj 2001;5(2):18-118.

17. Perek M., Krzeczowska B., Twarduś K.: Zachowania żywieniowe młodzieży $\mathrm{w}$ okresie dojrzewania. [Nutrional behaviors of youth during adolescence]. Ann Univ Mariae Curie Sklodowska 2007;185:196-201 (in Polish).

18. Pieszko-Klejnowska M., Stankiewicz M., Niedoszytko M.: Ocena sposobu odżywiania się gimnazjalnej 
młodzieży zamieszkującej wieś i miasto.[Evaluation of the diet of junior high school youth living in the village and the city]. Pediatr Współcz Gastroent Hepat Żyw Dziecka 2007;9(1):59-62 (in Polish).

19. Piotrowska E., Broniecka A., Frańczak M., Bronkowska M., Wyka J., Biernat J.: Wpływ warunków socjoekonomicznych na sposób żywienia i zwyczaje żywieniowe młodzieży 13-15-letniej z Wrocławia i okolic. [Influence of socio-economic conditions on the way of nutrition and eating habits of young people aged 13-15 from Wrocław and the surrounding area]. Bromat Chem Toksykol 2014;2:186 - 195 (in Polish).

20. Sitko D., Wojtaś M., Gronowska-Senger A.: Sposób żywienia młodzieży gimnazjalnej i licealnej. [Food patterns of youth from gymnasium and lyceum]. Rocz Panstw Zakl Hig 2012;63(3):319-327 (in Polish).

21. Sørensen L., Møller P., Flint A., Martens M., Raben A.: Effect of sensory percepon of foods on appete and food intake: A review of ttudies on humans. Int J Obes Relat Metab Disord 2003;27(10):1152-66.

22. Świderska-Kopacz J., Marcinkowski J., Jankowska K.: Zachowania zdrowotne młodzieży gimnazjalnej i ich wybrane uwarunkowania. Cz. IV. Sposób żywienia. [Health behaviour of secondary school pupils and its chosen determinants. Part IV. Nutritional habits]. Probl Hig Epidemiol 2008;89(2):241-245 (in Polish).

23. Vanhelst J., Béghin L., Duhamel A., De Henauw S., Ruiz J., Kafatos A., Androutsos O., Widhalm K., Mauro B., Sjöström M., Kersting M., Gottrand F. Clin Nut. 2017,doi: 10.1016/j.clnu.2016.10.019.

24. Wądołowska L.: Walidacja kwestionariusza częstotliwości spożycia żywności-FFQ. Ocena powtarzalności. [Validation of Food Frequency Questionnaire-FFQ]. Repeatability rating. Bromat Chem Toksykol 2005;38(1):27-33 (in Polish).

25. Zack R., Irema K., Kazonda P., Leyna G., Liu E., Gilbert S., Lukmanji Z., Spiegelman D., Fawzi W., Njelekela M., Killewo J., Danaei G.: Validity of an FFQ to measure nutrient and food intakes in Tanzania. Public Health Nutr 2018,doi: 10.1017/S1368980018000848.

26. Ziółkowska A., Gajewska M., Szostak-Węgierek D.: Zachowania żywieniowe młodzieży gimnazjalnej z Warszawy i miejscowości podwarszawskich. [Nutritional habits of secondary school students from Warsaw and the Warsaw vicinity]. Probl Hig Epidemiol 2010;91(4):606-610 (in Polish).

Received: 29.05.2018

Accepted: 10.08 .2018

This article is available in Open Access model and licensed under a Creative Commons Attribution-Non Commercial 3.0.Poland License (CC-BY-NC) available at: http://creativecommons.org/licenses/by-nc/3.0/pl/deed.en 